\title{
Human Capital Development and Employee Training as Correlates to Employee Job Performance in Redeemer University Ede, Osun State
}

\author{
Olonade, Zacceheaus, O. PhD \\ Department of Human Resource Management, \\ Faculty of Management Sciences \\ Osun State University, Osogbo \\ Omotoye Oluwatobi, O. ACIPM \\ Department of Employment Relations and Human Resource Management, \\ Faculty of Management Sciences \\ University of Lagos, Akoko.
}

Received: March 29, 2020 Accepted: April 21, 2020 Online published: April 29, 2020

doi:10.5296/ijhrs.v10i2.16933 URL: https://doi.org/10.5296/ijhrs.v10i2.16933

\begin{abstract}
The study examined Human Capital Development and Employee Training as correlates to Employee Job Performance in Redeemer University, Ede. This was for the purpose of ascertaining the significance of Human Capital Development and Employee Training on Employee Job Performance. The study embraced a survey research design using primary data to collect information through the use of questionnaire. One hundred (100) respondents were selected out of the Two Hundred and Forty Eight (248) members of staff of Redeemer University, Ede, Osun State, as at the time of the study. Two hypotheses were formulated and tested with Pearson Correlation and Linear Regression Analysis. Hypothesis one revealed that Human Capital Development significantly and positively influence Employee Performance [ $\mathrm{r}$ $\left.(98)=.401^{* *}, \mathrm{P}<0.01\right]$. Furthermore, the second hypothesis revealed that Employee Training has a significant contribution to employee job Performance in Redeemer University Ede, Osun State $(\mathrm{F}(2,97)=7.834, \mathrm{P}<.05, \mathrm{R} 2=0.139)$. The study recommended that the goals of Training and Development must be communicated to both the management and the staff of the University. The Performance Appraisal System need be used to identify areas in which
\end{abstract}


employees need further Training and Development in order to be more relevant to the needs of the University. Also, workers rewards is recommended to be enhanced so that they have a positive effect on their Job Performance. Finally, the management of the institution should come up with effective plans to advance the Job Security of employees, as Workers' Job Security is synonymous with Job Performance.

Keywords: human capital development, employee training, and employee job performance

\section{Introduction}

Human capital development is one among the foremost important requirements to make sure the sustenance and improvement of an economy either at the macro or micro level. Human capital development may be a continuous process from childhood to adulthood. It's also the foremost for any society or enterprise that wishes to survive under the complex challenges of the dynamic world. For the individual, it should be a life-long process thanks to the continuously changing environment to which one must also continuously adapt to. Such development enables the persons involved to maneuver vertically or laterally within the economic and social environment, (Ibok and Ibanga, 2014) averred.

In recognition of the importance of human capital development, the United National Economic Commission for Africa (1991) has described human capital development because the knowledge, skills, attitudes, physical and managerial effort required to control capital, technology, land, and material to supply goods and services for human consumption. In a very collaborative view, (Simkovic, 2013) sees human capital because the most significant element of success in business today. According to him, developing human capital requires creating and cultivating an environment within which personalities can rapidly learn and apply new ideas, competencies, skills, behaviors, and attitudes. It could, therefore, be deduced that human capital represents the stock of competencies, knowledge, habits, social and personality attributes, to supply measure.

More so, human capital development becomes part of an overall effort to realize cost-effective performance in a corporation, Maran (2009). Thus, the institution must understand human capital development that will enhance and improve employee job performance. It there means human capital refers to the talents and skills of human resources and within the other hand, human capital development refers to the method of acquiring and increasing the quantity of persons who have the abilities, training, and expertise which are critical for the survival of a corporation and economic process of the country at large, (Griffin and Knight, 1990). The study seeks to fill the gap of human capital development and training on employee job performance at Redeemer University Ede, Osun State.

\section{Statement of the Problem}

This study investigated the correlation between human capital development and training on employee job performance at Redeemer University Ede, Osun State. However, none of the prior studies have evaluated employee training along with other essentials of human capital improvement stated herein on employee job performance. This was to establish the factors that would facilitate effective human capital development and training for improved 
employee job performance at Redeemer University Ede, Osun State.

\section{Objectives of the Study}

Specifically, the targets of the study are to:

1. Determine the link between Human Capital Development and Employee Job Performance at Redeemer University Ede, Osun State.

2. Ascertain the contribution of Employee Training on Employee Job Performance at Redeemer University Ede, Osun State.

\section{Research hypotheses}

$\mathrm{Ho}_{1}$ : There's no correlation between Human Capital Development and Employee Job Performance at Redeemer University Ede, Osun State.

$\mathrm{Ho}_{2}$ : there's no significant contribution of Employee Training on Employee Job Performance at Redeemer University Ede, Osun State.

\section{LITERATURE REVIEW}

\section{Theoretical Review}

\section{Human Capital Theory}

The theory of human capital is rooted from the field of macroeconomic development theory (Schultz, 1993). Becker's (1993) classic book, Human Capital: A Theoretical and Empirical Analysis with special reference to education, illustrates this domain. Becker argues that there are different kinds of capitals that include schooling, a computer training course, expenditures on medical care. And in fact, lectures on the virtues of punctuality and honesty are capital too. In the true sense, they improve health, raise earnings, or add to a person's appreciation of literature over a lifetime. Consequently, it is fully in keeping with the capital Human Capital Development and Its Impact on Firm Performance: Evidence from Developmental Economics concept as traditionally defined to say that expenditures on education, training, and medical care, etc., are investment in capital. These are not simply costs but investment with valuable returns that can be calculated.

From the perspective of Classical Economic Theory, human capital considers labour as a commodity that can be traded in terms of purchase and sale. This classical theory very much focuses on the exploitation of labour by capital. However, unlike the meaning traditionally associated with the term labour, human capital refers to the knowledge, expertise, and skill one accumulates through education and training. Emphasizing the social and economic importance of human capital theory, Becker (1993) noted the most valuable of all capital is that investment in human being. Becker distinguishes firm-specific human capitals from general-purpose human capital. Examples of firm-specific human capital include expertise obtained through education and training in management information systems, accounting procedures, or other expertise specific to a particular firm. General-purpose human capital is knowledge gained through education and training in areas of value to a variety of firms such as generic skills in human resource development. Regardless of the application, Becker 
considers education and training to be the most important investment in human capital.

\section{Goal-Setting Theory}

The Goal Setting theory developed by Latham and Locke (1979) states that motivation and performance are higher when individuals set a particular goal, when goals are difficult but accepted and when there's feedback on performance. Precipitation in goal setting is very important as a method of getting agreement to the setting of upper goals. Difficult goals must be given and their achievement enforced by guidance and advice, finally, the feedback is significant in maintaining motivation, particularly towards the achievement of even higher goals. Goal Theory plays a key role in performance management, Armstrong (2009).

The effect of goal-setting on performance have been widely studied and validated. It is an approach to work motivation via conscious goals. The theory states that specific and difficult goals may lead to sustained task performance because of the intrinsic challenge within the job (Bartol \& Locke, 2000; Buchner, 2007). The theory's core premise is that the simplest and most direct motivational explanation of why some people perform better on work tasks than others is because they have different performance goals.

\section{Human Capital Development, Employee Training and Employee Job Performance}

Daniel, (2019) the study aimed to establish the relationship between Human capital management and organizational performance. The study had a population size of 152, out of which a sample size of 110 was realized using Taro Yamane formula at 5\% error to tolerance and $95 \%$ level of confidence. An instrument used for data collection was primarily a questionnaire. The total numbers of 110 copies of the questionnaire were distributed while 80 copies were returned. A descriptive research design was adopted for the study. Two hypotheses were tested using Pearson's moment correlation coefficient. The findings suggest that there was a significant relationship between human capital management and organizational performance. The necessity for human capital development includes teaching the skills and knowledge requires in new staff, upgrading the skills and knowledge of old employees, meeting the challenges of technological innovation acquiring the skills required in the competitive market and enhancing human capital resourcefulness. The study recommends that Human resource manager should ensure that proper identification, determination, and assessment of human capital needs in the organization.

Banu and Chandran, (2019) aimed to explore the impact of human capital management practices on job performance of employees working in the selected private sector banks in India. This empirical research was carried through the survey method and a structured questionnaire was used to gather the perception of private bank employees. The statistical tools such as percentage analysis, factor analysis, t-test and analysis of variance have been applied to draw the meaningful findings to the research objectives. The empirical evidence proves that five dominant underlying dimensions were found and labeled as Recruitment and Selection, Performance Appraisal, Training and Development, Carrier advancement, and Commitment in their order of dominance. This research concludes that proper recruitment and selection of bank employees and rationalized performance evaluations can give 
maximum benefit to their customers in the form of best service quality and satisfaction.

Chigozie, and Onyia (2018) the study was to evaluate the effect of human capital development in organizational performance in manufacturing industries in South-East Nigeria. The specific objective includes; ascertain the effect of knowledge on product quality and ascertain the relationship between skills and promoting innovation. The population consists of 6230 staff of selected manufacturing firms from South-East, Nigeria. The study used the survey approach. The primary sources used were the administration of a questionnaire to staff and distributors. The sample size of 358 was determined using Freund and William's formula. 306 copies of the questionnaire were returned and accurately filled. The validity of the instrument was tested using content analysis and the result was good. The reliability was tested using the Pearson correlation coefficient (r). It gave a reliability co-efficient of 0.88 which was also good. The hypotheses were analysed using the f-statistics (ANOVA) tool. The findings indicated that Knowledge has a positive significant effect on product quality $\mathrm{F}(95, \mathrm{n}=358)=2181, \mathrm{P}<0.05$; Skills have a positive significant relationship on promoting of innovations $\mathrm{F}(95, \mathrm{n}=358)=381.631, \mathrm{P}<0.05$; The study concluded that any organization that does not learn continuously and is not able to continuously list, develop, share, distribute, mobilize, cultivate, put to practice review and spread knowledge will not be able to compete effectively in the global market. The study recommended that it is important that organizations should be training their staff to enable them to acquire Knowledge to enhance productivity and the market share of the firms and Provision of new technological equipment and training of workers on the machines should be advised and encouraged for more profitability of the manufacturing companies.

Okafor, Ofobruku and Obi-Anike, (2019). The purpose of this investigation is to determine the effects of human capital development on employees' performance in Nigeria public hospital. The challenges of employees' performance in Nigeria public hospitals have persisted, regardless of the government effort on human capital development. The situation is made worst in that much prior studies on human capital development in Nigeria only focused on other sectors, with limited literature on human capital development in Nigeria public hospitals. To have a comprehensive insight into the issue of employees' performance in Federal Medical Hospital in Nigeria, this study utilized the survey approach. Data collected from the survey questionnaire were analyzed and tested using t-statistics generated from the model formulated for the three hypotheses. The data collected were analyzed using the linear regression statistical technique. Results indicated that human capital development activities in Nigeria hospital can be used to optimize employees' performance. In particular, the study found out that the lacks of articulate human capital development strategy geared towards filling identified skills, knowledge and attitude gap were responsible for the manager of employees' performance in Nigeria hospitals. Therefore, the study recommends specifically that for the human capital development process to be successful in Nigeria hospitals, there is a need for prearranged and integrated employees' development strategy. This should involve career support, training on-the-job and off-the-job training programs that are tailored towards filling the identified skills, knowledge and attitude gaps in Nigeria public hospitals.

Mahadeven, and Hsiiang (2019) the objective is to examine the impact of on-the-job and 
off-the-job training on employee performance. The researcher adopted a positivism research philosophy and collected quantitative primary data through a survey questionnaire. The questionnaire was designed based on various types of on-the-job and off-the-job training methods. Census method is adopted to collect data as the researcher distributed the questionnaire to all 162 employees in the target population providing an equal chance for all to participate in the study. 136 responses were returned however only 124 are accepted as the remaining was found to be incomplete. The collected data were analyzed using SPSS software to get the regression values. The result shows both on-the-job and off-the-job training achieve a standardized coefficients beta value of 0.370 and 0.546 respectively with a significant value of 0.000 which concludes the outcome of the research that on-the-job and off-the-job training has a positive significant impact on employee performance.

\section{METHODOLOGY}

Descriptive survey research method was used for the study. The population for the study, which comprised of all employees of Redeemer University, Ede, Osun State, as of January 2019 were Two-Hundred and Forty-Eight (248) members of staff. 100 respondents were used as sample size for the study, making $40 \%$ of the population. Simple random sampling technique was used for the distribution of the questionnaire. This gives every member of staff equal chance of being part of the study. Structured questionnaire was used for data collection. The questionnaire was divided into 4 sections. Section A consisted of Demographic Information, while Section B consisted of Human Capital Development Scale (HCDS). Sections C and D consisted of Employee Performance Scale (EPS), and Employee Training Scale (ETS) respectively. The measures used five-point Likert scales starting from Strongly Agree to Strongly Disagree. Reliability and validity tests were carried out on the questionnaire, and a reliability coefficient of 0.84 was obtained for the Instrument's reliability, and experts' concurrence obtained for validity. Data collected were subjected to Inferential and Descriptive Statistics. Specifically, the info were analyzed using the percentage and frequency counts for the demographic information, while Pearson Product Moment Correlation and Linear Regression were used for testing the hypotheses of the study. The formulated hypotheses were tested at 0.05 alpha levels.

\section{PRESENTATION OF RESULTS}

\section{Research Hypotheses}

Hypotheses One: There is no significant correlation between human capital development and employee Performance in Redeemer University Ede, Osun State. 


\section{Macrothink}

International Journal of Human Resource Studies

ISSN 2162-3058 2020, Vol. 10, No. 2

Table 1. A Summary Table of Pearson, $r$ Correlation showing the correlation between human capital development and employee job Performance

\begin{tabular}{|l|l|l|l|l|l|l|}
\hline & N & M & S D & Df & R & P \\
\hline Human Capital Development & 100 & 9.8400 & 2.55924 & 98 & $.401^{* *}$ & .000 \\
Employee Job Performance & 100 & 15.1733 & 3.74210 & 98 & & \\
\hline
\end{tabular}

**Correlation is significant at the 0.05 level (2-tailed).

The result in table 1 above revealed that Human Capital Development is positively correlated with employee job performance $\left[\mathrm{r}(98)=.401^{* *}, \mathrm{P}<0.05\right]$. Therefore, hypothesis one was not supported by the result of the study, and it is subsequently rejected. Thus, it is concluded that there is significant correlation between Human Capital Development and Employee Job Performance in Redeemer University Ede, Osun State.

Hypotheses Two: There is no significant contribution of training on employee job performance in Redeemer University Ede, Osun State.

Table 2. Summary of Linear Regression Analysis showing the combination of training on employee job performance in Redeemer University Ede, Osun State

\begin{tabular}{|c|c|c|c|c|c|}
\hline \multicolumn{6}{|c|}{ Model Summary } \\
\hline \multirow[t]{2}{*}{ Model 1} & \multirow{2}{*}{$\begin{array}{l}\mathrm{R}=0.373^{\mathrm{a}} \\
\text { Sum of square }\end{array}$} & \multirow{2}{*}{$\begin{array}{l}\mathrm{R}^{2}=0.139 \\
\mathrm{Df}\end{array}$} & \multicolumn{3}{|l|}{ Adj. $R^{2}=0.121$} \\
\hline & & & Mean square & $\mathrm{F}$ & Sig. \\
\hline Regression & 9.838 & 2 & 4.919 & 7.834 & $0.001^{\mathbf{b}}$ \\
\hline Residual & 60.912 & 97 & 0.628 & & \\
\hline Total & 70.750 & 99 & & & \\
\hline Variable & $\begin{array}{l}\text { Unstandardized } \\
\text { coefficient }(\beta)\end{array}$ & Std. error & $\begin{array}{l}\text { Standardized } \\
\text { coefficient }(\beta)\end{array}$ & $\mathrm{T}$ & Sig. \\
\hline Constant & 7.737 & 1.042 & & 7.427 & 0.844 \\
\hline $\mathrm{EP}$ & .110 & .058 & .145 & 1.879 & .000 \\
\hline
\end{tabular}

SPSS Computation, 2019

From table 2 above, R squared is 0.139 which indicated that Employee Job Performance contributed $13.9 \%$ of the total variation to the Employee Training of the respondents. With $\mathrm{F}$ $(2,97)=7.834, \mathrm{P}<.05, \mathrm{R}^{2}=0.139$. Hypothesis two was not supported by the result of the study, and it is subsequently rejected. Furthermore, training [t $(97)=1.879, \mathrm{P}<0.05]$ were independently predicts employee performance at $1 \%$ level respectively. Thus, it is concluded that employee training has a significant influence on employee job performance in Redeemer University Ede, Osun State. 


\section{Discussion of the Findings}

This study examined the importance of human capital development and employee training on employee job performance at Redeemer University Ede, Osun State.

The first hypothesis stated that there is no significant correlation between human capital development and employee Performance at Redeemer University was not supported by the result of the study. The result revealed that human capital development is positively correlated with employee job performance. The findings was supported by Daniel, (2019) that there was a significant relationship between human capital management and organizational performance. The necessity for human capital development includes teaching the skills and knowledge requires in new staff, upgrading the skills and knowledge of old employees, meeting the challenges of technological innovation acquiring the skills required in the competitive market and enhancing human capital resourcefulness. Also the findings was in line with results of Okafor, Ofobruku and Obi-Anike, (2019) which indicated that human capital development activities in Nigeria hospital can be used to optimize employees' performance. In particular, the study found out that the lacks of articulate human capital development strategy geared towards filling identified skills, knowledge and attitude gap were responsible for the meagre employees' performance in Nigeria hospitals.

The second hypothesis stated that employee training has no significant influence on employee job Performance at Redeemer University Ede, Osun State. The result revealed that employee training has a significant influence on employee performance. Therefore, hypothesis two was not supported by the result of the study, and it is subsequently rejected. This means that employees with a high level of training will perform more than the employee who has a low level of training. This result was supported by other studies that explain that staff employee training and development correlate highly with job performance. Mahadeven, and Hsiiang (2019) result shows both on-the-job and off-the-job training achieve a standardized coefficients beta value of 0.370 and 0.546 respectively with a significant value of 0.000 which concludes the outcome of the research that on-the-job and off-the-job training has a positive significant impact on employee performance.

\section{Conclusion}

We, therefore, concluded that human capital development enhances employee performance among employees in Nigeria Institution. This is evidence of a positive significant result revealed from the statistical test of hypotheses. The human development capital used in this study was employee training and it was discovered that all the hypotheses formulated are positively significant and therefore enhances performance.

Conclusively, the result of the analysis showed that human capital development and employee training are the stimulants that both institution and staff needs to increase their abilities that will in turn to improve their performance. Hence, the institution in Nigeria should invest more in their human capital in order to sustain their survival and maintain its competitiveness in the Nigeria Institution. 


\section{Recommendations}

Based on the findings of the study, the study recommended that the goals of training and development must be communicated to both management and the staff, also, the performance appraisal system must use to identify areas in which the workforce need further training and development in order to become relevant to the needs of the organization. Workers' rewards must be varied so that they have a positive effect on employee job satisfaction. Finally, the management of the institution should come up with effective plans to advance the job security of employees. Worker's job security is synonymous with organizational health.

\section{References}

Armstrong, M. (2009) Armstrong's Handbook of Human Resource Management Practice. 11th Edition, Kogan Page, London.

Banu, S., \& Chandran, M. (2019). Impact of Human Capital Management on Organizational Performance- A Study with Reference to Private Sector Banks. International Journal of Innovative Technology and Exploring Engineering, 8(7), 327-331.

Becker, G. (1993). Human capital: A theoretical and empirical analysis, with special reference to education. $3^{\text {rd }}$ Edition, New York: Colombia University Press. https://doi.org/10.7208/chicago/9780226041223.001.0001

Buchner, A. (2007). G*Power 3: A flexible statistical power analysis program for the social, behavioral, and biomedical sciences. Behavior Research Methods, 39(2), 175-191. https://doi.org/10.3758/BF03193146

Chigozie, M. P., AGA, C. C., \& Onyia, E. (2018). Effect of human capital development in organizational performance in Manufacturing Industries in South-East Nigeria. International Journal of Academic Research in Economics and Management Sciences, 7(3), 60-78.

Daniel, D. C. O. (2019). The effects of human capital development on organizational performance. International Journal of Scientific Research and Management, 7(1), 12-22. https://doi.org/10.18535/ijsrm/v7i1.em03

Griffin, K., \& knight, J. B. (1990). Human Development and the International Development strategy for the (1990s") Macmillan Basingstoke. Human System Management, 19(3), 193-203. https://doi.org/10.1007/978-1-349-21136-4

Ibok E., \& Ibanga, E. S. (2014). The impact of human capital development and economic empowerment on the socio-economic development of Akwa Ibom State, Nigeria

Latham, G., \& Locke, E. (1979). Goal setting-A motivational technique that works. Organizational Dynamics, 8(2), 68-80. https://doi.org/10.1016/0090-2616(79)90032-9

Mahadeven, A., \& Hsiiang, M. Y. (2019). Impact of Training Methods on Employee Performance in a Direct Selling Organization, Malaysia. Journal of Business and Management, 21(10), 07-14.

Mahroum, S. (2007). Assessing Human Resource for Science and Technology: The 3Ds 


\section{Macrothink}

International Journal of Human Resource Studies

ISSN 2162-3058 2020, Vol. 10, No. 2

Framework, Science and public policy, 34(7), 489-499. https://doi.org/10.3152/030234207X244838

Maran, M. (2008). Ethnic diversity on boards of directors and its implications on firm financial performance. The Journal of International Social Research, 1(4), 431-445.

Okafor, C. N., Ofobruku S. A., \& Obi-Anike H. O. (2019). An investigation of the effect of human capital development on employees' performance in Nigeria Public Hospitals: A study of the Federal Medical Hospital Keffi. Academy of Strategic Management Journal, 18(4) $1-13$.

Schultz, T. W. (1993). The economic importance of human capital in modernization. Education Economics, 1(1), 13-19. https://doi.org/10.1080/09645299300000003

Simkovic, M. (2013). Competition and Crisis in Mortgage Securitization (October 8, 2011). Indiana Law Journal, 88, 213. https://doi.org/10.2139/ssrn.1924831

Srivastava, A., Locke, E. A., \& Bartol, K. M. (2001). Money and subjective well-being: It's not the money, it's the motives. Journal of Personality and Social Psychology, 80(6), 959-971. https://doi.org/10.1037/0022-3514.80.6.959

\section{Copyright Disclaimer}

Copyright for this article is retained by the author(s), with first publication rights granted to the journal.

This is an open-access article distributed under the terms and conditions of the Creative Commons Attribution license (http://creativecommons.org/licenses/by/4.0/). 